EPiC Series in Biological Sciences
Volume 1, 2021, Pages 91-95
$\begin{gathered}\text { Proceedings of KOBI 2nd International Confer- } \\ \text { ence on Management of Tropical Biodiversity for } \\ \text { Human Welfare: From Ecosystem to Molecular }\end{gathered}$

\title{
Interactive Multimedia on Invertebrate Topic for Pre-service Biology Teacher
}

\author{
Nawawi ${ }^{1}$, Mustika Sari ${ }^{1}$, Henny Sulistiany ${ }^{1}$ \\ ${ }^{1}$ IKIP PGRI Pontianak, Pontianak, Indonesia \\ nawawi@ikippgriptk.ac.id
}

\begin{abstract}
This research was conducted at the Biology Education Study Program IKIP PGRI Pontianak. Indonesia. This study adopts Research and Development (R\&D) methods to create interactive multimedia learning resources about invertebrates developed from the Hanafin and Peck models. Three experts and 66 students were involved in this study. The results show that interactive multimedia is valid and therefore suitable for use in invertebrate teaching. The data shows that the media is effective for maximizing cognitive learning outcomes by $77.27 \%$. It can be concluded that this media has a positive impact on the learning process. It is projected that the media will also have an impact on student learning outcomes.
\end{abstract}

\section{Introduction}

The development of technology and information has an impact on the world of education in Indonesia, which is currently known as the Industrial Revolution 4.0 era. The use of technology and information in biological learning activities is needed to make students more motivated in learning activities. In this era, teachers are expected to have the ability to (a) utilize the optimal learning resources in the learning process, (b) create and develop new ideas, (c) reduce the knowledge gap that learners gain from schools with the knowledge they will gain, (d) clarify the relevance and the relation in community real life, (e) develop the knowledge, skills, and behavior of students gradually and intact (Rachmadtullah et al., 2018).

The problem that is often faced by teachers in schools is that there is an assumption that learning biology is boring, in which students feel that learning is only filled with storytelling activities because the materials are delivered in one-way learning. Moreover, teachers tend to ask students to memorize many materials, such as scientific names, diagrams, and various mechanisms of organ systems. As consequences, students are ashamed to ask, being lack of motivation, less enthusiastic, and lazy to do assignments, as well as getting sleepy, disordered, and having less concentration (Ariyanto et al., 2018). These conditions will cause the knowledge that has been taught will not be inherent in the long-term 
memory system of the students. Teachers are required to improve their role and competencies because competent teachers will be able to create an effective learning atmosphere and will be more competent in their class management (Saggaf et al., 2017).

The above learning paradigm must be changed, and students must be active in every learning activity. Meanwhile, learning media is a tool to improve the teaching and learning process to achieve better learning outcomes (Ariyanto et al., 2018). Teachers should be able to discuss and communicate with students to stimulate their cognitive, psychomotor, and affective skills. Learning activities must be interesting, innovative, and creative so that students get their own experience while learning biology. Interactive multimedia can be used to present an animated and video display so that it can improve student's understanding of the material and be able to replace the direct learning experience (Ramadhani \& Muhtadi, 2018). According to Arsyad (2011), the use of teaching media at the teaching orientation stage will greatly assist the effectiveness of the learning process and the delivery and the content of the lessons at the same time. The use of the teaching media will also improve the student's motivation, interest, and increase the student's understanding. Moreover, teachers can present data more attractively and reliable with condensed information but easy in interpretation.

Teachers must explore the factors that cause the failure in academic learning achievement, of both internal and external factors such as a low level of intelligence, lack of learning motivation, ineffective ways of learning, lack of frequency and amount of study time, low levels of self-discipline, and lack of learning media or teaching materials. According to Shah (2018), satisfying learning achievement can be achieved by an increasingly advanced education system and supporting technological developments using multimedia technology. Therefore, the teacher should explore their potential to change the way someone in learning and obtaining information during the learning process.

Students at the biology education study program of IKIP PGRI Pontianak were having difficulty in studying the invertebrate zoology course. The students haven't recognized most of the invertebrate animals presented in the laboratory because some of the students live far away from the coastal areas. They also had difficulty in identifying and classifying the invertebrate animals. According to Anifatunssholihah et al. (2018), the course materials of invertebrate not only presented many phyla and scientific names which were difficult to understand, but also that students had to memorize those scientific names of that many species. In the Animalia chapter, students are demanded to attain the basic competence which is applying classification concept for categorizing an animal to its phylum based on the morphology and anatomy characteristic, presenting data about a comparison of the complexity of animal body compiler and its function in life (Permendikbud, 2016).

In this research, multimedia was designed and tested its feasibility to be one solution in solving problems to teach invertebrate materials that were focused on the cognitive aspects. According to Ramadhani \& Muhtadi (2018), the use of multimedia has positive impacts on students including more interesting and interactive learning process, proper division of course material content in teaching time, more student's motivation, independent and time flexibility in the teaching and learning process, and improved and more focused student's attention.

\section{Materials and Methods}

The research was conducted in the Biology Education Study Program of IKIP PGRI Pontianak. This research used Research and Development (R\&D) method design with Hannafin and Peck's model (Tegeh, 2014), The development model carried out in this study used the Hannafin and Peck which consists of three stages, namely 1) needs assessment; 2) design and 3) development and evaluation. The first stage of the needs assessment was done by the identification of potential and problems. In this stage, the researcher analyzed invertebrate material to develop concepts that will be presented through instructional media interactively using Macromedia Flash. In the design stage, researchers collected 
materials from various sources which are then used in designing interactive invertebrate learning media. As for some the steps taken are the preparation of the subject matter, the preparation of the programming language in Macromedia Flash, the preparation of the script as a whole, and editing the learning media. The design of interactive invertebrate learning media uses the Indonesian language according to the standard needs of the school to make it easier for students to understand.

The media content started from the title of the course material, instructions for using invertebrate interactive learning media, the learning goals, core material, and supporting video. The validation of interactive learning media was conducted by the media expert and by the material experts. The media validity was measured based on the aspects of software engineering, learning design, and visual communication, meanwhile, the material validity was measured based on course material (in this case material of invertebrates), illustration and animation, quality, and capability, and attractiveness of the learning media. The percentage of eligibility for each aspect is presented in Table 1. Student respondents $(\mathrm{n}=66)$ were recruited from the Biology Education Study Program of IKIP PGRI Pontianak Academic Year 2018/2019. Data collection was using questionnaires, meanwhile, product media validation was using the Percentage of Eligibility which is combined with interview guides. Qualitative data were included from the suggestion and comment from media and material experts.

\begin{tabular}{llc}
\hline Validation Type & \multicolumn{1}{c}{ Criteria } & Percentage of Eligibility (\%) \\
\hline Media & Software Engineering & 30 \\
& Software Learning design & 45 \\
\multirow{3}{*}{ Material } & Visual Communication & 25 \\
& Course Material & 30 \\
& Illustration and Animation & 25 \\
& Quality and Capability & 20 \\
& The attractiveness of the Learning Media & 25 \\
\hline
\end{tabular}

Table 1: Validation Aspects of Interactive Learning Multimedia on Invertebrates

\section{Results and Discussion}

Multimedia development adopted Hannafin and Peck's models. The first stage of the needs assessment was done by the identification of potential and problems. Researchers conducted a literature study, analyze the standard competency and learning objectives to be achieved so that the media developed would be appropriate for the course material of invertebrates in university. Material analysis needs to be done by identifying graduate achievements, learning outcomes referring to sub-learning objectives or special abilities to be achieved (Sudarman, Riyadi, \& Astuti, 2019).

In the biology department, invertebrate is studied in the zoology study course. According to Widiansyah et al. (2018), the object of the invertebrate zoology study includes the characteristics of morphology, anatomy, physiology, habitat, and the role of invertebrates in the ecosystem. The result of the first step was: 1) researchers need about 5 months from starts until final media revision, 2) the material experts were biology lecturer and media experts were information technology and computer lecturer in IKIP PGRI Pontianak. Product development resulting from the research and development is presented in Table 2. The multimedia validation by the media expert got an average score of $88.24 \%$ or categorized into feasible to use. This shows that learning media meets the aspects of software engineering, learning design aspects, and visual communication aspects. Interactive learning media meets the aspects of software engineering with a percentage of eligibility of 23.53 and is categorized as feasible to use. The learning media used fulled aspects of maintainability, usability, compatibility, and reusable. The Learning Media has fulfilled the learning design aspects with a percentage of the 
feasibility is $43,14 \%$ and categorized as feasible. The learning media used to meet the aspects of illustration and animation to Pre-service Biology teachers in understanding the material.

\begin{tabular}{lc}
\hline Criteria & Percentage of Eligibility (\%) \\
\hline Software Engineering & 23.53 \\
Software Learning Design & 43.14 \\
Visual Communication & 21.57 \\
Total & 88.24 \\
\hline
\end{tabular}

Table 2: Recapitulation of the Media Validation Results of Interactive Learning Multimedia on Invertebrates

The learning media has fulfilled aspects of visual communication with a percentage of eligibility of $21.57 \%$ and is categorized as feasible. In this category, the learning media was used to meet the creative, visual, moving media, and interactive layout aspects. However, the media experts suggested increasing the interactivity in the learning media by adding quizzes and interactive questions to each sub-material with at least 10 multiple-choice questions. Also, the learning media is made a storage area with a more attractive design.

\begin{tabular}{lcc}
\hline \multirow{2}{*}{ Criteria } & \multicolumn{2}{c}{ Percentage (\%) of validation result by } \\
\cline { 2 - 3 } & $1^{\text {st }}$ Material Expert & $2^{\text {nd }}$ Material Expert \\
\hline Invertebrate Content Material & 26,67 & 28,89 \\
Illustration and Animation & 20,00 & 22,22 \\
The Quality and Capability of the Learning & 17,78 & 20,00 \\
Media & & \\
The Attractiveness of the Learning Media & 20,00 & 20,00 \\
Total Validation Result & 84,45 & 91,11 \\
Average Validation Result & & 87,78 \\
Standard deviation & 3,85 & 4,21 \\
\hline
\end{tabular}

Table 3: Recapitulation of Material Validation Results for Interactive Learning Multimedia on Invertebrates

Table 3 shows the result of multimedia validation by two material experts with an average of $87.78 \%$ and the category is very feasible. The material is relevant to the basic competencies and learning objectives to be achieved. After validation by media experts and material experts, then proceed with teaching using interactive learning media that have been developed. The test for learning outcomes to the pre-service biology teacher was used to study the effectiveness of learning media being developed. The use of video was very effective in helping teachers explain in more detail about invertebrate material. Figure 1 shows the student using multimedia.

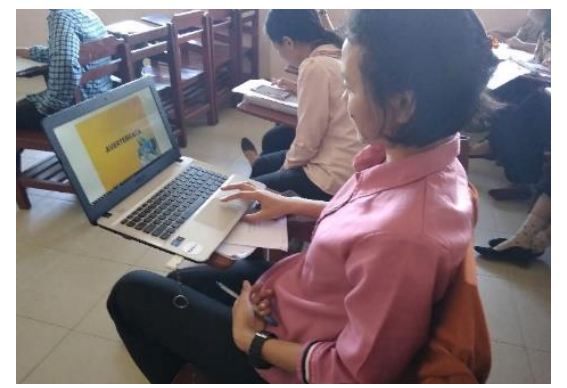

Figure 1: Student respondents used Interactive Multimedia on Invertebrate Zoology course 
After media and material validations, then proceed with class trials to understand the effectiveness of the use of interactive multimedia learning media. Based on the learning outcomes of all student respondents $(n=66), 77.27 \%(n=51)$ of the students met the minimum completeness standard $(>75 \%)$, and only 15 individuals of pre-service biology teacher have not yet completed. The results obtained are in line with Astuti \& Nurcahyo (2019) in which adobe flash is one of the suitable multimedia used in the biology learning process because the presented information has two visual modalities plus hearing called double coding.

The advantages of this interactive learning media on invertebrate learning are that interactive learning media is easy to use, does not take long duration in their use, display media adapted to certain invertebrate materials, the material can also be presented with a video. These results are in line with Astuti \& Nurcahyo (2019) which states that adobe flash-based learning media is the right choice in the use of educational media in the learning process with high-level abstract material. This research and development conclude that the resulted interactive multimedia on invertebrates was feasible based on media and material validation aspects by media and material experts, as well as in the product test to the user in the biology learning process.

\section{References}

Ariyanto A, Priyayi DF, and Dewi L. (2018). Penggunaan media pembelajaran biologi di sekolah menengah atas (sma) swasta salatiga. In Bahasa. BIOEDUKASI, 9(1): 1-13.

Anifatussholihah A, Utami NR, and Subekti N. (2018). The Influence of Guided Inquiry Learning Using Flash Based Invertebramedia on the Senior High School Students' Learning Achievement. Journal of Biology Education, 7(2): 137-143.

Astuti E and Nurcahyo H. (2019). Development of Biology Learning Media Based on Adobe Flash to Increase Interest and Conceptual Understanding. In Journal of Physics: Conference Series (Vol. 1241, No. 1, p. 012050). IOP Publishing.

Permendikbud. (2016). Permendikbud No. 22 tentang Standar Proses Pendidikan Dasar dan Menengah. In Bahasa. Jakarta: Kemendikbud.

Rachmadtullah R, Ms Z, and Sumantri MS. (2018). Development of computer-based interactive multimedia: a study on learning in elementary education. Int. J. Eng. Technol, 7(4): 2035-2038.

Ramadhani R and Muhtadi A. (2018). Development of Interactive Multimedia in Learning Islamic Education. International Journal of Multicultural and Multireligious Understanding. 5(6): 9-15.

Saggaf MS, Salam R, and Rifka R. (2017). The Effect of Classroom Management on Student Learning Outcomes. In International Conference on Education, Science, Art, and Technology (pp. 98102).

Sudarman S, Riyadi R, and Astuti RF. (2019). Development of Interactive Learning Multimedia to Increase Understanding of Basic Skills Teaching Procedures. 2nd Educational Sciences International Conference (ESIC 2019), Advances in Social Science, Education and Humanities Research, volume 432. (pp. 132-136). Atlantis Press. 